\title{
Buyer-Supplier Collaboration in New Product Development Between Two Equally Powerful Firms: A Case Study of ABB and SKF
}

\author{
Lisa Melander \\ Linköping University, SE-581 83Linköping, Sweden \\ Email: lisa.melander@afconsult.com
}

\begin{abstract}
Collaboration in new product development (NPD) is becoming ever more important as firms specialize and rely on suppliers to provide the latest technology. Most studies on supplier involvement are of collaborations between a powerful buyer and a less powerful supplier, and taking the buying firm's perspective. In contrast, this study focuses on a collaborative NPD project between two equally powerful firms, including both firms' perspectives. A case study of a project between ABB and SKF was conducted. It is shown that not only is the supplier selection important, but it is also important for the buying firm to have an attractive project to motivate the supplier to join the project. Such attractions include business opportunities and learning possibilities. However, these learning possibilities could be viewed as harmful by the buying firm. Particularly when considering that the supplier was equally powerful. Fear of knowledge spillover that could make it possible for the supplier to become a future competitor could hinder the collaboration. These fears were avoided mainly through trust built during prior history with the supplier project.
\end{abstract}

Keywords: NPD, supplier involvement, power, supplier selection, case study

\section{INTRODUCTION}

Firms collaborate with suppliers in new product development (NPD) in order to gain access to suppliers' technology. It is important to many firms to integrate new technology into their products, especially large system integrators, since many use multiple technologies (Brusoni et al. 2001; Takeishi, 2002). Collaboration with suppliers is common; a survey made by the Boston Consulting Group (BCG) shows that most firms collaborate with their suppliers. However, it seems that these firms mainly focus on operational efficiency and thus miss opportunities for collaborative product development (Tevelson et al. 2013). Similarly, academic studies have shown that firms can gain more from collaborating with competent suppliers (Lau et al. 2010; van Echtelt et al. 2008; Wasti and Liker, 1999). Hence, it is important to make a thorough supplier selection. Von Corswant and Tunälv (2002 p. 253) show the importance for firms to collaborate with suppliers in NPD by stating that in most of the cases studied "... the achieved product development performance would not have been realized without involving the suppliers." However, there are challenges related to involving suppliers in NPD, for instance the buying firm does not have complete control of the project and is dependent on the supplier.
The literature review on supplier involvement made by Johnsen (2009) points out that most studies that have been conducted have included large powerful buyers collaborating with less powerful suppliers. Hence, there is a lack of studies that investigate collaboration in NPD where the buying and supplying firm are equally powerful. Collaboration between two equally powerful firms poses other challenges for the buying firm. The firm needs to motivate the supplier to join the NPD project, and also consider that there is a possibility that the supplier could become a competitor in the future.

Most studies take the buying firm's perspective (Johnsen, 2009), while fewer take the supplier's perspective (LaBahn and Krapfel, 2000) and these studies involve small suppliers (Walter, 2003). Hence, the purpose of this paper is to study a collaborative NPD project between two equally powerful firms, taking both the buying firm's and the supplier's perspective into consideration. The focus is on why the two firms joined the collaborative NPD project and the implications for buying firm due to that the supplier was equally powerful. The outline of the paper is as follows. First, supplier collaboration in NPD is described, thereafter the chosen methodology is presented. Following is the case description and finally discussions and conclusions are provided.

\section{SUPPLIER COLLABORATION IN NPD}

\subsection{Supplier Selection}

A recent survey shows that identifying and selecting suppliers for NPD collaborations is particularly important when aiming to improve the firm's innovation performance (Bengtsson et al. 2013). Firms may evaluate a supplier's capabilities, making sure that the supplier has the required competence and that it is able to jointly collaborate in an NPD project. Research shows that suppliers are evaluated according to two categories; (i) technological capabilities and (ii) relational capabilities (Feng et al. 2010; Handfield et al. 1999; Wagner and Hoegl, 2006). In addition to these two broad classifications, cost is another criteria (Hoegl and Wagner, 2005). However, cost is not as important in situations of high technological uncertainty (such as in NPD) in comparison with supplier selection in situations where there is little or no technological uncertainty (for example basic manufacturing). In basic manufacturing, cost is one of the most important selection criteria (Ho et al. 2010). Previous research has argued that suppliers are diverse with respect to their capabilities, and that 
collaborative partnerships should be reserved for suppliers with outstanding technology and sophisticated management (Kamath and Liker, 1994).

In product development, firms rely upon specialized suppliers for components and sub-systems. The specialization of such suppliers is often related to the specific technology they use for producing a specific component/sub-system. Therefore, firms need to be technically competent in order to properly assess a suppliers' technology (von Corswant and Tunälv, 2002). For some technologies, there are many competing suppliers, while for others, there are only a few. Additionally, some technologies or specific components may be proprietary to only one supplier. Whether the technology is critical for the product or not also affects the selection process. If the technology is critical to the product and the number of available suppliers is limited, then a detailed technological assessment of the potential supplier should take place (Handfield et al. 1999).

Despite the importance of technological capabilities, a survey study on assembly industries (McCutcheon et al. 1997) stresses the importance of relational capabilities, arguing that, for future NPD projects, the supplier's cooperativeness can be more important than its technological capabilities. Particularly in situations with uncertainty, studies indicate that technological competencies are not enough, firms also need to have cooperative competencies (Melander and Tell, 2014; Tyler 2001). It is important for firms to be able to collaborate easily within an NPD project. One aspect of this is demonstrated in a case study of a company in the electronic industry by McIvor et al. (2006), who stress the importance of having a culture that facilitates and encourages collaboration between the firm and its supplier.

Searching for suppliers, collecting information on them, and assessing suppliers can be costly and timeconsuming. Therefore, firms may be inclined to collaborate with suppliers who have participated in the firms' previous NPD projects. In the process of selecting a supplier, survey studies of R\&D collaborations highlight the importance of having prior collaborations with the supplier (Håkanson, 1993; Li et al. 2008). A study of over one thousand R\&D alliances suggests that firms prefer to select suppliers who are well-known (Li et al. 2008).

It should be emphasised that firms need to make careful selections with respect to suppliers, because the partner that seems most capable may not be the most suitable for the firm's needs (Diestre and Rajagopalan, 2012). Firms need to consider the long-term orientation of the suppliers, because long-term orientation facilities collaboration under technological uncertainty (Emden et al. 2006). In addition, firms need to establish a careful balance between long-term relationships with some suppliers, while inviting new suppliers to participate NPD (Clark and Fujimoto, 1991).

\subsection{Collaboration in NPD Projects}

Collaboration is important, as shown by several studies that point to an increased need for firms to involve external actors in NPD (Chesbrough, 2003; Gupta and Wilemon, 1990). Suppliers are recognized to improve buying firms' development process, product quality and cost (Abidin et al.
2012).

Studies show that firms focus on developing their capabilities for innovation (Börjesson et al. 2014), however, they also collaborate with external partners. Among potential partners, suppliers are considered to be important sources of innovation (Bengtsson et al. 2013; CuervoCazurra and Un, 2010).

Specialisation results in a division of labour and knowledge, making firms dependent on suppliers for providing new technology. Studies show that the main objective for involving suppliers in NPD is to gain access to technology and technological expertise, and to enjoy the supplier's insights during the design process (Birou and Fawcett, 1994). It is suggested that firms should collaborate with firms who differ from the buying firm, in order to increase the benefits from the collaboration. In fact, collaboration with partners that are similar to the firm gives fewer benefits than partners that are diverse (Baum et al. 2000) since similar firms provide less diverse pools of information and know-how. However, it may be more difficult to collaborate with firms that are different than with firms that are similar, since similar firms share knowledge bases and pre-understandings (Johansson et al. 2011).

In collaborations, it is possible for firms to tap into the other party's knowledge and technology. Even though a partner can be trusted to develop a part of a product, it is important to have knowledge about all the different technologies that are involved in a product. It is also crucial to have knowledge of different technologies and technology trajectories (Caputo and Zirpoli, 2002) that could be relevant for the firm in the future. In order to be efficient in collaborative product development, the work can be divided between the parties. The buying firm needs to decide who will undertake the design and engineering work (development), and what responsibility the supplier should have (Clark and Fujimoto, 1991). However, the possibility of dividing work is limited depending on the type of problem that is to be solved, and how the problem is to be solved (Brusoni, 2005). Managing the project entails (i) division of work and assigning work tasks inside and outside the firm, and (ii) organization of activities inside and outside the firm (Clark and Fujimoto ,1991). With respect to how the firms will manage the relationship between each other, the buying firm's own competence and ability to control the relationship are primarily considered (Zirpoli and Camuffo, 2009).

Firms may seek to control the NPD projects and the suppliers involved in these projects. However, there are a number of challenges that are related to control in NPD. These are presented by McDermott (1999) as a lack of control of suppliers, a fear of losing control of the NPD, poor communication with suppliers, and internal coordination. Control also involves having control of the firm's technology. In collaborations, it is possible for the supplier to gain knowledge about the firm's technology. Such an information leak could have severe implications, since the firm can lose their advantage towards competitors or the supplier may become a future competitor. Thus, the form of governance in R\&D collaborations is influenced by the possibility of the firm losing control of technological assets (Oxley and Sampson, 2004). 


\section{METHODOLOGY}

This paper is based on a case study of an NPD project where the buying firm and the supplier collaborated to develop a new component to be implemented in the buying firm's product. Performing a case study is a method to systematically study a phenomenon, and is recommended for the study of a complex unit which has multiple variables (Merriam, 1998). In the supply chain management field of research, case studies are valuable as they collect rich data (Kähkönen, 2011).

The sampling process consisted of finding suitable firms, project, and respondents to interview. The firm $\mathrm{ABB}$ and their supplier SKF were selected to study, these firms are market leaders in their respective industries and can be expected to demonstrate 'best practice' in collaborative NPD. During the sampling process at the initial meeting, the technical manager at $\mathrm{ABB}$ presented several NPD projects involving external suppliers. The chosen project was successful, involved new technology, and included a powerful international supplier, namely SKF. The technical manager contacted the supplier, and when the supplier agreed to be included in the study, the project was selected.

The technical manager (the gate-opener) identified the project team members at $\mathrm{ABB}$ and the key account manager at
SKF. The key account manager then provided access to SKF's project team members. At both firms, the complete project teams were interviewed. The main data was collected during interviews with individuals who were involved in the NPD projects. Semi-structured interviews were conducted in order to gain in-depth responses about each respondent's experience, perceptions, and knowledge (Patton, 2002). By using openended questions, predetermination of answers and a limitation of discussion points were avoided. Moreover, such questions allows for an understanding of the respondent's point of view without assuming pre-determined categories.

The study began by conducting semi-structured interviews at $\mathrm{ABB}$, with the employees involved in the NPD project. This project team comprised of four project members; the project manager, the technical manager, the supply manager, and the general manager. After completing the interviews at $\mathrm{ABB}$, the study at the supplier SKF began. The supplier's project team were interviewed, consisting of the key account manager, the project manager, an application engineer, a development engineer, the product manager, and a business engineer. Table 1 lists the project members who were interviewed for their respective companies, the duration of the interviews, and each project member's role(s) in the project.

Table 1. List of Interviews

\begin{tabular}{lllc}
\hline Respondent & Firm & Duration & Number of interviews \\
\hline Project Manager & ABB & $1 \mathrm{~h} 30 \mathrm{~min}$ & 1 \\
Technical Manager & ABB & $2 \mathrm{~h} 30 \mathrm{~min}(1 \mathrm{~h}, 1 \mathrm{~h} 30 \mathrm{~min})$ & 2 \\
Supply Manager & $\mathrm{ABB}$ & $2 \mathrm{~h}$ & 1 \\
General Manager & $\mathrm{ABB}$ & $1 \mathrm{~h} 30 \mathrm{~min}$ & 1 \\
Key Account Manager & $\mathrm{SKF}$ & $2 \mathrm{~h}$ & 1 \\
Project Manager & $\mathrm{SKF}$ & $1 \mathrm{~h} 30 \mathrm{~min}$ & 1 \\
Application Engineer & $\mathrm{SKF}$ & $1 \mathrm{~h} 30 \mathrm{~min}$ & 1 \\
Development Engineer & $\mathrm{SKF}$ & $1 \mathrm{~h} 30 \mathrm{~min}$ & 1 \\
Product Manager & $\mathrm{SKF}$ & $1 \mathrm{~h} 15 \mathrm{~min}$ & 1 \\
Business Engineer & $\mathrm{SKF}$ & $1 \mathrm{~h} 15 \mathrm{~min}$ & 1 \\
Total & & $16 \mathrm{~h} 30 \mathrm{~min}$ & 11 \\
\hline
\end{tabular}

Secondary data (mainly documents) were collected from internal organisational documents, brochures, home pages, and technical information documents. This data was used to define the characteristics of the industries and firms, the characteristics of the products, and the history and organisation of the firms. To gather information about the products, factory visits with guides were made and a technical fair was visited. Extensive marketing materials were studied, including videos, catalogues, brochures, presentations, and information sheets. Additionally, competitor suppliers were studied through their homepages, brochures, and other marketing materials. Innotrans, the world's largest railway fair was visited in order to learn more about the railway industry. ABB, SKF, and their potential customers and competitors participated at Innotrans.

The collected data was analysed, organised, categorised, and coded to facilitate the analysis for the case study. Using the interview-data that was collected, a microanalysis was made, which took the interviewees' interpretations of the projects into consideration (Strauss and Corbin, 1998). Eisenhardt (1989) recommends within-case analysis in case study research, which includes detailed case write-ups (Yin, 2009). A careful examination of the collected data was conducted, and it was thereafter classified into groups according to its properties and similarities. In this study, time lines were created to facilitate an understanding of important milestones in the projects. In this chronological mapping, core situations were identified and interpreted. Furthermore, detailed case descriptions were written in which the respondents' views of important episodes are presented.

Reliability refers to whether it is possible for another researcher to follow the procedures of the first researcher and conduct the same case study again. But because each NPD project is unique it may not be possible to repeat a study of a project and reach the same findings. However, to ensure that it is hypothetically possible, documents of the procedures that were following during the study are needed. Yin (2009) recommends researchers to use case study protocols and to develop a case study database during the data collection phase of a study. During the case study, a case study database was created, which included the recorded interviews, transcriptions, notes and different documents that were collected, as well as case write-ups. 


\section{CASE STUDY: ABB AND SKF}

The NPD project's aim was to develop a new set of bearings for ABB's new traction motor. The duration of the project was about one year, and both firms had project teams working on the project to reach the expected result. The supplier SKF owns the bearings that have been developed, and it was the buyer ABB's application data and motor data that were used to develop suitable bearings. SKF and ABB developed seven bearings that could be used for a range of motors.

\subsection{Starting the Project}

ABB has a history of 100 years of manufacturing traction motors and SKF has been manufacturing bearings for over 100 years. These two firms have a long tradition and much experience with their respective products, including technical expertise in their fields. In the NPD project, $\mathrm{ABB}$ performed problem identification, an assessment and a selection of available technologies and suppliers, which is shown in Figure 1. First, the problem with bearing current was identified as a key issue in several of the areas for improvement, which needed to be addressed in the new design of the traction motor. In this paper, bearing current is defined as the problem of electrical current which runs through the bearing and can cause bearing failure. Technologies that were available to solve the problem were identified and evaluated at ABB. Three possible technologies existed and the technology that was perceived to be the best choice was selected. Thereafter, well-known bearing suppliers were assessed and evaluated. The most suitable supplier, among three possible suppliers, was chosen based on selection criteria that will be presented later in this paper.

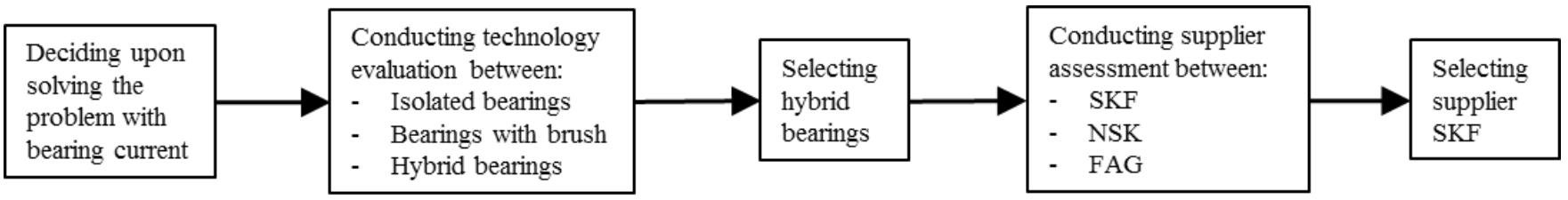

Figure 1. ABB's Technology and Supplier Selection

The assessment of different possible technologies to solve the problem of bearing currents was made at ABB with the involvement of an external expert. The most common solution for the problem with bearing currents in the railway industry is isolated bearings, which are bearings with an isolated coat to prevent electrical current from running through the bearing. However, isolated bearings do not fully protect against bearing current. The problem can also be solved by using a standard steel bearing and ground the bearing with a brush. This technique has flaws since the brush will wear down and needs maintenance. A hybrid bearing was a good solution to the problem since the rolling elements were made of ceramic. Hybrid bearings have other positive attributes; not only do they insulate and protect from bearing currents, but ceramic is a very light weight material which makes it possible to rotate such bearings at very high speeds. It can also handle aggressive environments where standard steel bearings would rust, and the greasing intervals are longer which increases the mileage before maintenance. Thus, hybrid bearings have several positive characteristics compared to the other bearing solutions. The reason for the limited use of hybrid bearings today is the cost level; hybrid bearings are considered to be an expensive product. In order to develop hybrid bearing for the motor ABB needed to collaborate with a supplier, as it does not have expertise in bearings in-house.

ABB's assessment of potential suppliers started with initial discussions with these suppliers. There were several factors for selecting SKF but technology expertise was vital. "SKF was selected because they are at the front end in this technology" (General Manager, ABB). Further factors included a demonstrated interest from SKF for the NPD project and openness to initial discussions. Additionally, SKF demonstrated to $\mathrm{ABB}$ that they believed that the product could be a success, and supported ABB's initial ideas. Other important factors were ABB's and SKF's long history of collaboration, and ABB's previous positive experience from working with SKF.

When ABB presented the idea of collaboration, SKF believed in the project and the product's market potential in the railway industry. "A prerequisite for SKF to join this project was to see its potential" (Application Engineer, SKF). Furthermore, an assessment to determine the potential of the project was made. One benefit of joining the NPD project was the acquisition of knowledge, but as one project member at SKF emphasized, the focus was on the business potential; "Knowledge acquisition can be a benefit, working with customers that are in the front end and are thinking in new ways is beneficial for SKF, but in the end what is important is that the project results in business for us" (Application Engineer, SKF). In addition, a long tradition of working with ABB was another reason for SKF to join the NPD project. Another important issue for SKF was that the project should strategically fit to SKF's business. "Railway is a very important industry for our products, hybrid is a very important product line for us, and Sweden is a very important market. So from a strategic point it was a very good fit" (Product Manager, SKF). Hence, to start the collaboration was very much a common interest to both firms.

\subsection{Collaboration Between Two Similar Firms}

During the NPD project, integration was believed to be facilitated by the firms' similarity and compatibility. The purpose of project was clear and specified from the beginning; the target was often referred to in meetings and discussions. "We have had a common vision and that was enormously important, also the technical specification was of utmost importance" (Project Manager, SKF). Additionally, SKF viewed ABB's project team as a creative group where development was fast. SKF perceives its own firm as an innovative company as well. 
The integration was made possible due to commitment and team spirit; the two firms were struggling towards the same goal: the new product. It was a prioritized project at both $\mathrm{ABB}$ and SKF, which gave the project speed and facilitated integration. The importance of priority was described, by a member in the SKF project team, this way: "If you enter a project with a partner and the subject for the partner is not as important as it is for you, then it's difficult to move forward. For us, hybrid is priority number 1. For $A B B$ development of this motor was priority number 1. So then, automatically both organisations try to move forward. If we had hybrid as priority number 3 or number 4 it would probably have been much more difficult" (Product Manager, SKF).

$\mathrm{ABB}$ did not have any intentions of making the component only accessible for ABB. The technology belonged to SKF, and ownership of the developed product was important to both firms. For ABB it was important not to have 'an $\mathrm{ABB}$ product' but a product that SKF could sell to other companies. This was because ABB wanted to make the product well known and accepted in the industry, and to increase volumes of the product in order to lower the cost. SKF, on the other hand, wanted to have ownership of the product since it was SKF's technology. Moreover, the possibility of increasing sales was another factor for SKF to demand ownership of the product.

Both $\mathrm{ABB}$ and SKF perceived that openness existed in the NPD project and that the project members could be frank with each other. "The openness was a positive ingredient. It was one reason why the project went so well" (Application Engineer, SKF). Consequently, SKF was straightforward towards $\mathrm{ABB}$ and pointed out problems in specifications and demands that needed to be discussed, which opened up for joint discussions between the two firms. Additionally, ABB was not afraid of being open or sharing too much information about the traction motor, since vital parts are protected through patents. "For a collaboration to function, it is vital to eliminate secrets by being open" (Technical Manager, ABB). SKF had a similar view of openness in the project: "Definitely it is easier with openness, for sure" (Product Manager, SKF).

Trust was an issue that both ABB and SKF mentioned as an important factor in the collaboration. "Trust has played a very important part in this project" (Supply Manager, ABB). In this project, there existed two types of trusts; confidence in the other firm and a belief in the developed product. The sense of a win-win situation for both firms made participation positive and was the foundation for building a further more trustful relationship. During the whole project, $\mathrm{ABB}$ trusted SKF and had confidence that SKF would manage to develop the component. History and past experience played a part in creating confidence that SKF could deliver what was promised. In addition, SKF had confidence in ABB and respected ABB's opinions regarding the outlook for the project. Furthermore, $\mathrm{ABB}$ was described as a good partner: "A good partner is if you have the same targets and you openly work together to get to this target. A difficult partner is if you constantly have to watch out, that he doesn't take advantage" (Product Manager, SKF).

\section{DISCUSSION AND CONCLUSIONS}

The results of the study show that supplier selection is important, and that firms need to consider not only the suppliers' technology but also how well the firms work together. Similarly, many studies stress the importance of making a careful assessment of suppliers before selecting one for NPD projects (Handfield and Lawson, 2007; Hoegl and Wagner, 2005; Petersen et al. 2005; Surjandari et al. 2010; Un et al. 2010). In this project, the buying firm had to convince the supplier to join the project. As the firms were viewed as equally powerful, it was not for certain that the supplier would want to join the project although the buying firm had selected it. Table 2 shows an overview of the buying firm's selection criteria and the reasons for the supplier to join the project.

Table 2. Summary of Selection Criteria and Supplier's Considerations

\begin{tabular}{l}
\hline Buying firm's considerations in supplier selection \\
\hline Stability and profitability \\
History \\
Product quality \\
Cost level \\
Expertise \\
Advanced technology \\
Technical skills \\
Innovative reputation \\
Trust
\end{tabular}

The reasons for the two firms for wanting the other as a collaboration partner varied somewhat, however, trust was emphasized from both firms. The fact that the two firms were viewed as equally powerful affected the collaboration and the culture within the project. Previous studies show that firms' power position affects the character of the relationship between parties in buyer-supplier relationships (Kähkönen and Lintukangas, 2010). There were many discussions between the firms and a consensus culture was developed during meetings.

Johnsen (2009 pp 195) argues that most research "tends to assume that suppliers are willing to invest in - and commit to the customer's demanding NPD projects". However, that was not the case in this study. Here the buying firm needed to

Supplier's considerations for joining the project
Business potential
Good strategic fit
No exclusivity
Market interest
Previous work relations
Learning possibilities
Trust
Open to discussions
Believing in the project

motivate the supplier to join and collaborate in the project. Hence, the studied project differs from other studies, where the supplier is the weaker party facing large and powerful buyers (LaBahn and Krapfel, 2000). One motivation for suppliers to join a collaborative NPD project is when the buying firm has technical innovativeness (LaBahn and Krapfel, 2000). From such collaborations the supplier can learn from the buying firm. It is suggested that to motivate suppliers to join NPD collaborations, buying firms should encourage and enable suppliers to participate in NPD, by focusing more on the relationship between the firms and thus gaining the suppliers' trust and commitment (Walter, 2003). In this study, both firms 
experienced benefits from the collaboration, both in form of learning and also in business opportunities.

The buying firm also had to consider the implications from having an equally powerful partner, in particular the possibility of the supplier becoming a future competitor (Melander and Tell, 2014). This was avoided by clearly stating the intentions of the project, discussing close collaboration and trusting in the supplier's business plans for the future. Previous relations with the supplier were important in establishing and trusting its intentions. Hence, fear of knowledge spillover was limited and instead the firms could exchange information, discuss solutions and learn from each other.

There may be a number of limitations to this study, but by choosing the case study method it was possible for the researcher to gain a certain richness of data and to develop existing ideas (Stuart et al. 2002). A common critique to the method is its limitation in terms of generalizability, however, the aim of this study is to give a detailed account of an NPD collaboration, not to generalize towards larger populations. The case selection that was made implied other limitations. For example, the study employs a dyadic approach, but, alternatively, triads could have been studied by selecting cases that involved three organizations, for example.

To collaborate with an external firm (in this study, a supplier) involves many interesting research topic. Previous studies on supplier involvement have focused on integration (Petersen et al. 2005), coordination (Lakemond et al. 2006), joint location (Lakemond and Berggren, 2006), technology roadmaps (Petrick and Echols, 2004), technological uncertainties (Melander and Tell, 2014), knowledge sharing (Tell, 2011), trust (Das and Teng, 1998), and a number of other related issues concerning supplier involvement in NPD projects. However, there is still much to be explored, particularly in collaboration between equally powerful firms taking both firms' perspectives (Johnsen, 2009).

\section{REFERENCES}

Abidin, A. S. Z., Muslimen, R., Yusuff, R. M., Zulkifli, N., Ismail, M. Y., and Bakar, N. A. (2012), An Exploratory Study on the Critical Success Factors for Design Capabilities Development, Operations and Supply Chain Management 5 (1), pp. 14-26.

Baum, J. A. C., Calabrese, T., and Silverman, B. S. (2000), Don't go it alone: Alliance network composition and startups' performance in Canadian biotechnology, Strategic Management Journal 21 (3), pp. 267-294.

Bengtsson, L., Lakemond, N., and Dabhilkar, M. (2013), Exploiting supplier innovativeness through knowledge integration, International Journal of Technology Management 61 (3), pp. 237-253.

Birou, L. M., and Fawcett, S. E. (1994), Supplier involvement in integrated product development: a comparison of US and European practices, International Journal of Physical Distribution \& Logistics Management 24 (5), pp. 4-14.

Brusoni, S. (2005), The limits to specialization: problem solving and coordination in 'Modular Networks', Organization Studies 26 (12), pp. 1885-1907.

Brusoni, S., Prencipe, A., and Pavitt, K. (2001), Knowledge specialization, organizational coupling, and the boundaries of the firm: Why do firms know more than they make? Administrative Science Quarterly 46 (4), pp. 597-621.

Börjesson, S., Elmquist, M., and Hooge, S. (2014), The challenges of innovation capability building: Learning from longitudinal studies of innovation efforts at Renault and Volvo Cars, Journal of Engineering and Technology Managemen 31, pp. 120-140.

Caputo, M., and Zirpoli, F. (2002), Supplier involvement in automotive component design: outsourcing strategies and supply chain management, International Journal of Technology Management 23 (1), pp. 129-159.

Chesbrough, H. (2003), The era of open innovation, Sloan Management Review 44 (3), pp. 35-41.

Clark, K. B., and Fujimoto, T. (1991), Product development performance: Strategy, organization, and management in the world auto industry, Harvard Business Press.

Cuervo-Cazurra, A., and Un, C. A. (2010), Why Some Firms Never Invest in Formal R\&D, Strategic Management Journal 31 (7), pp. 759-779.

Das, T. K., and Teng, B.-S. (1998), Between trust and control: Developing confidence in partner cooperation in alliances, Academy of Management Review, pp. 491512.

Diestre, L., and Rajagopalan, N. (2012), Are all 'sharks' dangerous? new biotechnology ventures and partner selection in R\&D alliances, Strategic Management Journal 33 (10), pp. 1115-1134.

Eisenhardt, K. (1989), Building theories from case study research, Academy of Management Review 14 (4), pp. 532-550.

Emden, Z., Calantone, R. J., and Droge, C. (2006), Collaborating for new product development: selecting the partner with maximum potential to create value, Journal of Product Innovation Management 23 (4), pp. 330-341.

Feng, B., Fan, Z. P., and Ma, J. (2010), A method for partner selection of codevelopment alliances using individual and collaborative utilities, International Journal of Production Economics 124 (1), pp. 159170.

Gupta, A. K., and Wilemon, D. L. (1990), Accelerating the development of technology-based new products, California Management Review 32 (2), pp. 24-44.

Handfield, R., Ragatz, G., Peterson, K., and Monczka, R. (1999), Involving Suppliers in New Product Development? California Management Review 42 (1), pp. 59-82.

Handfield, R. B., and Lawson, B. (2007), Integrating suppliers into new product development, ResearchTechnology Management 50 (5), pp. 44-51.

Ho, W., Xu, X., and Dey, P. K. (2010), Multi-criteria decision making approaches for supplier evaluation and selection: A literature review, European Journal of Operational Research 202 (1), pp. 16-24.

Hoegl, M., and Wagner, S. M. (2005), Buyer-supplier collaboration in product development projects, Journal of Management 31 (4), pp. 530.

Håkanson, L. (1993), Managing cooperative research and development: partner selection and contract design, $R \& D$ Management 23 (4), pp. 273-285.

Johansson, M., Axelson, M., Enberg, C., and Tell, F. (2011), "Knowledge integration in inter-firm R\&D relationships: How do firms balance problems of 
coordination with problems of cooperation?", in A. Bergek, M. Hobday, C. Berggren, L. Bengtsson \& J. Söderlund, (ed.), Knowledge Integration and Innovation: Critical Challenges Facing International Technology-based Firms, Oxford: Oxford University Press.

Johnsen, T. E. (2009), Supplier involvement in new product development and innovation: Taking stock and looking to the future, Journal of Purchasing and Supply Management 15 (3), pp. 187-197.

Kamath, R. R., and Liker, J. K. (1994), A Second Look at Japanese Product Development, Harvard Business Review 72 (6), pp. 154-170.

Kähkönen, A.-K. (2011), Conducting a case study in supply management, Operations and Supply Chain Management 4 (1), pp. 31-41.

Kähkönen, A.-K., and Lintukangas, K. (2010), Dyadic relationships and power within a supply network context, Operations and Supply Chain Management 3 (2), pp. 59-69.

LaBahn, D., and Krapfel, R. (2000), Early Supplier Involvement in Customer New Product Development: A Contingency Model of Component Supplier Intentions, Journal of Business Research 47 (3), pp. 173-190.

Lakemond, N., and Berggren, C. (2006), Co-locating NPD? The need for combining project focus and organizational integration, Technovation 26 (7), pp. 807-819.

Lakemond, N., Berggren, C., and Weele, A. (2006), Coordinating supplier involvement in product development projects: a differentiated coordination typology, $R \& D$ Management 36 (1), pp. 55.

Lau, A. K. W., Tang, E., and Yam, R. (2010), Effects of Supplier and Customer Integration on Product Innovation and Performance: Empirical Evidence in Hong Kong Manufacturers, Journal of Product Innovation Management 27 (5), pp. 761-777.

Li, D., Eden, L., Hitt, M. A., and Ireland, R. D. (2008), Friends, acquaintances, or strangers? Partner selection in R\&D alliances, Academy of Management Journal 51 (2), pp. 315-334.

McCutcheon, D. M., Grant, R. A., and Hartley, J. (1997), Determinants of new product designers' satisfaction with suppliers' contributions, Journal of Engineering and Technology Management 14 (3-4), pp. 273-290.

McDermott, C. M. (1999), Managing radical product development in large manufacturing firms: a longitudinal study, Journal of Operations Management 17 (6), pp. 631-644.

McIvor, R., Humphreys, P., and Cadden, T. (2006), Supplier involvement in product development in the electronics industry: a case study, Journal of Engineering and Technology Management 23 (4), pp. 374-397.
Melander, L., and Tell, F. (2014), Uncertainty in collaborative NPD: Effects on the selection of technology and supplier, Journal of Engineering and Technology Management 31, pp. 103-119.

Merriam, S. B. (1998), Qualitative Research and Case Study Applications in Education. Revised and Expanded from "Case Study Research in Education.", JosseyBass Publishers, San Francisco.

Oxley, J. E., and Sampson, R. C. (2004), The scope and governance of international R\&D alliances, Strategic Management Journal 25 (8-9), pp. 723-749.

Patton, M. Q. (2002), Qualitative research and evaluation methods, Thousand Oaks, CA: Sage Publications., California.

Petersen, K., Handfield, R., and Ragatz, G. (2005), Supplier integration into new product development: coordinating product, process and supply chain design, Journal of Operations Management 23 (3-4), pp. 371388.

Petrick, I. J., and Echols, A. E. (2004), Technology roadmapping in review: A tool for making sustainable new product development decisions, Technological Forecasting and Social Change 71 (1), pp. 81-100.

Strauss, A., and Corbin, J. (1998), Basics of qualitative research: Techniques and procedures for developing grounded theory, Sage Publications, Inc, Thousand Oaks.

Stuart, I., McCutcheon, D., Handfield, R., McLachlin, R., and Samson, D. (2002), Effective case research in operations management: a process perspective, Journal of Operations Management 20 (5), pp. 419-433.

Surjandari, I., Sudarto, S., and Anggarini, S. (2010), Supplier selection in JIT automotive industry: a multivariate approach, Operations and Supply Chain Management 3 (2), pp. 83-93.

Takeishi, A. (2002), Knowledge partitioning in the interfirm division of labor: The case of automotive product development, Organization Science, pp. 321-338.

Tell, F. (2011), "Knowledge integration and innovation: a survey of the field", in C. Berggren, A. Bergek, L. Bengtsson, M. Hobday, and J. Söderlund, (eds.), Knowledge integration and innovation: Critical challenges facing international technology-based firms. New York: Oxford, pp. 20-60.

Tevelson, R., Alsén, A., Rosenfeld, P., Benett, S., Farrell, P., and Zygelman, J. (2013), Buyer-Supplier Collaboration A Roadmap for Success, BCG perspectives, Aug (2013), pp. 1-7.

Tyler, B. B. (2001), The complementarity of cooperative and technological competencies: a resource-based perspective, Journal of Engineering and Technology Management 18 (1), pp. 1-27.

Lisa Melander has a $\mathrm{PhD}$ from Linköping University in Sweden in industrial organisations. Her research interests include collaborative new product development, supplier selection, supplier integration, project management and procurement strategy. She has conducted research at companies such as ABB, Ericsson and SKF. Today Lisa works as a consultant at ÅF in Gothenburg, where she conducts studies on growth, competitiveness and challenges for industrial firms in the western region of Sweden. 